\title{
Private Damages Actions in EU Competition Law and Restorative Justice: Towards a More Streamlined Institutional Framework?*
}

\author{
Pieter Van Cleynenbreugel ${ }^{* *}$
}

\begin{abstract}
The transposition of Directive 2014/104 on private damages actions marks an important development in the setting up of a harmonised private competition law enforcement regime across different EU Member States. Coupled with deterrence-focused public enforcement, the European Union has taken a necessary and welcomed step towards enhancing justice for all those individuals and competitors damaged by competition law infringements. This article argues, however, that the current emphasis on balancing public and private enforcement of the European Commission focuses too little on the need and healing effects of restoration. At the same time, the Directive contains a promising restorative justice opening by virtue of its Article 18. Starting from that opening, the article will propose a more developed way forward, taking the form of the setup and development of so-called antitrust "trust funds". Exploring the legal possibilities and limits of such funds, the article questions to what extent this approach could be a useful complementary way to overcome the limits identified. It will be submitted that, although it is legally possible to set up those trust funds under EU law, important practical questions have to be addressed prior to doing so. Having outlined the potential features and limits of this approach, the article additionally calls for more and comparative research to be performed in this area.
\end{abstract}

KEYWORDS: EU competition law, private enforcement, Directive 2014/104, restorative justice, collective actions

\footnotetext{
* Date of reception: 29 June 2019. Date of acceptance: 28 August 2019.

DOI: https://doi.org/10.7559/mclawreview.2019.1826.

** Professor of European Union law and Directeur, Liège Competition and Innovation Institute (LCII), Université de Liège, Belgium - Visiting professor of competition law, Université ParisDauphine, France; pieter.vancleynenbreugel@uliege.be.
} 


\section{Introduction}

The transposition of Directive 2014/104 on private damages actions ${ }^{1}$ marks an important development in the setting up of a harmonised private competition law enforcement regime across different EU Member States. ${ }^{2}$ Coupled with deterrence-focused public enforcement in place for a much longer time $e^{3}$, the European Union has taken a necessary and welcomed step towards enhancing justice for all those individuals and competitors damaged by competition law infringements. The system set up by this Directive and its ambition to complement existing public enforcement will contribute to bringing more and better justice to antitrust law victims. ${ }^{4}$

Despite its obvious advancements in terms of justice for individuals, this article argues that the current emphasis on balancing public and private enforcement of the European Commission focuses too little on the need and healing effects of restoration. As a result, the private damages Directive addresses some of the main concerns that gave rise to its development only partially.

At the same time, however, Article 18 of the Directive contains an important opening towards setting up a more developed restorative justice-oriented institutional framework at EU and Member States level. In light of that opening, this article aims to push that reflection somewhat forward by contemplating the setup and development of so-called antitrust "trust funds" as alternative institutional arrangements for restorative justice. By antitrust "trust funds", the article refers more specifically to a private entity managed by public authorities tasked with setting up and developing a wide variety of restorative justice initiatives in the realm of competition law. Inspired by the framework of charitable trusts and their regulation under English law, the article calls upon public authorities to investigate the development of this figure in EU competition law

\footnotetext{
${ }^{1}$ Directive 2014/104/EU of the European Parliament and of the Council of 26 November 2014 on certain rules governing actions for damages under national law for infringements of the competition law provisions of the Member States and of the European Union, [2014] OJ L349/1 (hereafter referred to as 2014 Directive).

${ }^{2}$ See Max Hjärtstrom and Julian Nowag, "EU competences and the Damages Directive: The continuum between minimum and full harmonisation", in EU Competition Litigation. Transposition and First Experiences of the New Regime, eds. Magnus Strand, Vladimir Bastidas and Marios Iacovides (Oxford: Hart, 2019), 4-5.

${ }^{3}$ Wouter PJ Wils, "Private enforcement of EU antitrust law and its relationship with public enforcement: Past, present and future", World Competition 40, no. 1 (2017), 3-4.

${ }^{4}$ See also Ioanis Lianos, Peter Davis and Paolisa Nebbia, Damages Claims for the Infringement of EU Competition Law (Oxford: Oxford University Press, 2015), 412.
} 
enforcement as well. It will be argued that trust funds could be a vehicle for restorative justice-focused conversations and working meetings that take place between offender and victim, yet mediated with some public oversight. Exploring the legal possibilities and limits of such funds at both EU and Member State levels, the article questions to what extent this approach could be a useful complementary way to overcome the limits identified. It can be submitted indeed that taking such an approach would be a useful way to overcome the frictions and gaps prevailing in the current public enforcement-private enforcement distinction underlying EU competition law.

In developing that argument, the article will be structured into two main parts. The first part summarises well-known debates on the extent to which the 2014 Directive complements the public enforcement system. Revisiting those debates, it will be argued that the current EU competition law enforcement framework gives rise to a narrow understanding of corrective justice likely to limit the scope and ambitions of a more developed restorative justice-oriented competition law enforcement framework. At the same time, Article 18 of the Directive contains an important opening to address restorative justice more prominently within the realm of private competition law enforcement (2.). Building on that opening, the article subsequently explores the legal possibilities and limits of an alternative restorative justice approach situated between public and private enforcement and takes somewhat of a more European approach to collective restorative justice mechanisms: the antitrust trust fund managed by public authorities. The article will flag the questions associated with setting up such funds and the legal and practical limits that would need to be addressed within the context of EU legal order (3.).

It deserves to be mentioned at the outset that the claim this article makes is neither to abolish the current private damages action regime in place nor to end discussions on the usefulness and future of the introduction of collective actions as an alternative remedy in EU competition law enforcement. ${ }^{5}$ The main aim is indeed only to explore whether, as a matter of EU law, setting up such trust funds could be a possibility. As a result, the analysis in this article is limited to EU law. Although useful comparisons could - and deserve to - be made between the proposals made here and

\footnotetext{
${ }^{5}$ Within that context, discussions on how to improve collective actions' attractiveness also take place, see e.g. Charlotte Leskinen, "Collective actions: Rethinking funding and national cost rules”, Competition Law Review 8, no. 1 (2011): 87-121.
} 
U.S. collective enforcement mechanisms ${ }^{6}$, the role of trust administrators in the common law and the role of courts play as like-minded institutional actors in distributing and allocating damages to and beyond ${ }^{7}$ groups of damaged individuals or competitors ${ }^{8}$, this article deliberately chooses only to focus on the state of play in EU competition law. It is hoped that, by sketching at this stage the possibilities for a more developed restorative justice approach and the institutional developments it may require, a fruitful academic and policy debate can be initiated and more developed comparative research efforts can be engaged in in the years to come.

\section{Private damages actions: a step forward, yet insufficiently paying attention to restorative justice in competition law enforcement} The adoption and transposition of Directive 2014/104 on certain rules governing actions for damages under national law for infringements of the competition law provisions of the Member States and of the European Union is a huge step forward in the setup and design of a more varied competition law enforcement mechanism. This section revisits the context in which the 2014 Directive came to be (a.) prior to revisiting the focus on monetary compensation the Directive reflects (b.). That focus is essentially grounded in a corrective justice approach, although potential openness towards more restorative justice processes can also be found to be present (c.).

\section{a. The context of the 2014 Directive}

At the EU level, both public and private enforcement essentially have a complementary role to play. Public enforcement reflects above all deterrence-oriented procedures and processes, resulting in the imposition of administrative or, in some Member States, criminal fines. ${ }^{9}$ In addition, acceptance of commitments, immunity tools in response to leniency

\footnotetext{
${ }^{6}$ Promising work has been done in that regard by Zygimantas Juska, The Role of Collective Redress Actions to Achieve Full Compensation for Violations of European Union Competition Law (Leiden University PhD thesis, 2019), 237.

${ }^{7}$ In so-called cy près or cypres settlements see, for a critical appraisal of that concept, Jennifer Johnston, "Cy pres comme possible to anything is possible: How cy pres creates improper incentives in class action settlements", Journal of Law, Economics \& Policy 9 (2013): 277-304.

${ }^{8}$ See, on that question, Deborah Hensler, "Can private class actions enforce marketplace regulations? Do they? Should they?", in Comparative Law and Regulation Understanding the Global Regulatory Process, eds. Francesca Bignami and David Zaring (Cheltenham: Edward Elgar, 2016), 238-272.

${ }^{9}$ Michael Frese, Sanctions in EU Competition Law: Principles and Practice (Oxford: Hart, 2016), 135.
} 
applications or other settlement techniques aim to soften a bit too restrictive or vigorous enforcement. Those mechanisms aim to reward those that bring to light uncovered competition law, yet do not as such detract from public enforcement's primary ambition, which is to deter businesses from engaging in anticompetitive behaviour. ${ }^{10}$ Deterrence, despite being understood in different ways and through different means, remains at the heart of public enforcement within the EU and its Member States. ${ }^{11}$

As part of private enforcement, injunctions can be brought before national courts asking to establish the voidness of anticompetitive agreements or decisions. Injunctive relief is one of the key techniques of private enforcement, allowing parties to a contract or third parties to invoke the nullity/voidness of that contract. ${ }^{12}$ On top of those contractual remedies, private damages actions exist as well, either standing alone or following on to a public enforcement decision. ${ }^{13}$ In addition to contributing to individuals being compensated for harm, the mere presence of potential damages actions is also supposed, in a supplementary way, to have a deterrent effect on businesses. ${ }^{14}$ The same could be said of injunctions, allowing businesses to think twice before concluding an anticompetitive - void - agreement. ${ }^{15}$ As a result, the different public and private enforcement techniques in vogue aim at deterrence and compensation. The way in which a legal order organises and balances public and private enforcement reflects, in that regard, a certain deterrence-compensation balance.

\footnotetext{
${ }^{10}$ On how leniency fits deterrence, see Wils, "Private enforcement", 33.

${ }^{11}$ See Marco Motta, "On cartel deterrence and fines in the European Union", European Competition Law Review, 29, no. 4 (2008): 209-220. The Commission makes this clear in its fining guidelines, see Commission Guidelines on the method of setting fines imposed pursuant to Article 23(2) (a) of Regulation No. 1/2003, [2006] O.J. C210/2, point 37. See also Damien Geradin and David Henry, "The EC fining policy for violations of competition law: An empirical review of the Commission Decisional Practice and the Community Courts' judgments", European Competition Journal 1, no. 2 (2005): 401-473.

${ }^{12}$ See Caroline Cauffman, "The impact of voidness for infringement of Article 101 TFEU on related contracts", European Competition Journal 8, no. 1 (2012): 95-122 for an analysis of those remedies. ${ }^{13}$ See, for a general perspective, David Ashton and David Henry, Competition Damages Actions in the EU (Cheltenham: Edward Elgar, 2013), 3-4.

${ }^{14}$ Sofia Oliveira Pais and Anna Piszcz, "Package on actions for damages based on breaches of EU competition rules: Can one size fit all?", Yearbook of Antitrust and Regulatory Studies 7, no. 10 (2014), 211.

${ }^{15}$ Lars Henriksson, "Private enforcement of public law - an inconsistent approach to remedies?", in EU Competition Litigation: Transposition and First Experiences of the New Regime, eds. Magnus Strand, Vladimir Bastidas and Marios Iacovides (Oxford: Hart, 2019), 80.
} 
Within this enforcement context, debates on private damages actions in EU competition law go back to the $1960 \mathrm{~s}^{16}$, yet have regained importance with the Banks Opinion of Advocate General Van Gerven. In his Opinion, Van Gerven held that the infringement by a private individual of rights granted to other individuals under EU law could give rise to private damages actions for infringement of those EU rights. ${ }^{17}$ The Advocate General opined that this right could apply in the context of EU competition law - in particular in relation to Articles 101 and 102 TFEU - as well..$^{18}$ The recognition of the possibility of damages actions in the Courage ${ }^{19}$ and Manfredi ${ }^{20}$ judgments confirmed that private damages actions could be part of the EU competition law enforcement apparatus. Indeed, from that moment onwards, "any individual can claim compensation for the harm suffered where there is a causal relationship between that harm and an agreement or practice prohibited under Articles 101 or 102 TFEU". ${ }^{21}$ However, "in the absence of [EU] rules governing the matter, it is for the domestic legal system of each Member State to designate the courts and tribunals having jurisdiction and to lay down the detailed procedural rules governing actions for safeguarding rights which individuals derive directly from [EU] law, provided that such rules are not less favourable than those governing similar domestic actions (principle of equivalence) and that they do not render practically impossible or excessively difficult the exercise of rights conferred by [EU] law (principle of effectiveness)".22 As a result,

\footnotetext{
${ }^{16}$ European Commission, La Réparation des Conséquences Dommageables d'une Violation des Articles 85 et 86 du Traité Instituant la CEE, Série Concurrence No. 1 (Brussels, European Commission, 1966). See also Assimakos Komninos, EC Private Antitrust Enforcement: Decentralised Application of EC Competition Law by National Courts (Oxford: Hart, 2008), 163. See, for background also, Folkert G. Wilman, "The end of the absence? The growing body of EU legislation on private enforcement and the main remedies it provides for", Common Market Law Review 53, no. 4 (2016), 887-888.

${ }^{17}$ Opinion of Advocate General Van Gerven delivered on 27 October 1993, H. J. Banks Co. Ltd v. British Coal Corporation, C-128/92, EU:C:1993:860, paragraph 43.

${ }^{18}$ Opinion of Advocate General Van Gerven delivered on 27 October 1993, H. J. Banks Co. Ltd v. British Coal Corporation, C-128/92, EU:C:1993:860, paragraph 44.

${ }^{19}$ Judgment of 20 September 2001, Courage Ltd v. Bernard Crehan, C-453/99, EU:C:2001:465, paragraph 26 .

${ }^{20}$ Judgment of 13 July 2006, Vincenzo Manfredi v. Lloyd Adriatico Assicurazioni SpA and Others, C-295/04 to C-298/04, EU:C:2006:461.

${ }^{21}$ Judgment of 13 July 2006, Vincenzo Manfredi v. Lloyd Adriatico Assicurazioni SpA and Others, C-295/04 to C-298/04, EU:C:2006:461, paragraph 61.

${ }^{22}$ Judgment of 13 July 2006, Vincenzo Manfredi v. Lloyd Adriatico Assicurazioni SpA and Others, C-295/04 to C-298/04, EU:C:2006:461, paragraph 62.
} 
absent EU harmonisation, the setup and structure of private damages actions remained with Member States' procedural autonomy. ${ }^{23}$ Although the overall aim of such private damages actions was not explicitly confirmed by the Court of Justice, it can be inferred from the judgments that, in addition to its deterrent effect ${ }^{24}$, the overall objective of a right to compensation is to guarantee individuals a right to damages, a right to be corrected for the harm that has been inflicted upon them. Corrective justice, the reversal of wrongs, is therefore key in developing and designing such private damages actions.

From 2005 onwards, the Commission sought to harmonise private damages actions, taking the need for more deterrence and a better deterrence-compensation balance into account. According to the Commission, Articles 101 and 102 TFEU are "enforced both by public and private enforcement. Both forms are part of a common enforcement system and serve the same aims: to deter anti-competitive practices forbidden by antitrust law and to protect firms and consumers from these practices and any damages caused by them. Private as well as public enforcement of antitrust law is an important tool to create and sustain a competitive economy". ${ }^{25}$ Within that context, deterrence is the key objective. That is further confirmed by the Commission in its claim that "[d]amages actions for infringement of antitrust law serve several purposes, namely to compensate those who have suffered a loss as a consequence of anti-competitive behaviour and to ensure the full effectiveness of the antitrust rules of the Treaty by discouraging anti-competitive behaviour, thus contributing significantly to the maintenance of effective competition in the [EU] (deterrence). By being able effectively to bring a damages claim, individual firms or consumers in Europe are brought closer to competition rules and will be more actively involved in enforcement of the rules" ${ }^{26}$ Deterrence remains the

\footnotetext{
${ }^{23}$ Pieter Van Cleynenbreugel, "Embedding procedural autonomy: The Directive and national procedural rules", in Harmonising EU Competition Litigation: The New Directive and Beyond, eds. Maria Bergström, Magnus Strand and Marios Iacovides (Oxford: Hart, 2016), 99-119; Katri Havu, 'Full, adequate and commensurate compensation for damages under EU Law: A challenge for national courts?', European Law Review 43, no. 1 (2018): 24-46.

${ }^{24}$ Judgment of 20 September 2001, Courage Ltd v. Bernard Crehan, C-453/99, EU:C:2001:465, paragraph 27.

${ }^{25}$ Commission of the European Communities, Green Paper - Damages actions for breach of the EC antitrust rules $\{$ SEC(2005) 1732\}, COM2005(672) final, https://eur-lex.europa.eu/legal-content/ $\mathrm{EN} / \mathrm{TXT} / \mathrm{PDF} /$ ?uri=CELEX:52005DC0672\&from=EN 3.

${ }^{26}$ Commission, Green Paper, 4.
} 
key objective in that understanding, in addition to and complementary with the original corrective justice objectives underlying the Court's early steps in this field.

The subsequent preparatory documents, most notably the 2007 Commission's White paper on damages actions ${ }^{27}$ and the 2009 European Parliament Resolution that followed $\mathrm{it}^{28}$, also confirmed that posture. Although those documents gave rise to significant discussions on how to streamline public and private enforcement best, most notably in terms of access to leniency document ${ }^{29}$ and the establishment of a fault by national judges with or without a previous decision by a competition authority ${ }^{30}$, the underlying objective of deterrence coupled with individuals' ability to receive compensation has not been questioned since. ${ }^{31}$ A 2007 study investigating the potential impact of a private damages action instrument on competition law enforcement even explicitly referred to both deterrence and corrective justice as ambitions of EU's private enforcement regime.

\section{b. The compensatory focus of the 2014 Directive}

The 2014 Directive also reflects this balance between deterrence and corrective justice, the former playing the key role in its setup. ${ }^{32}$ According to the Directive's recitals, "[a]ctions for damages are only one element of an effective system of private enforcement of infringements of competition

\footnotetext{
${ }^{27}$ European Commission, White paper on damages actions for breach of the EC antitrust rules \{SEC(2008) 404\} \{SEC(2008) 405\} \{SEC(2008) 406\}, COM2008(165)final, https://ec.europa.eu/competition/antitrust/actionsdamages/files_white_paper/whitepaper_en.pdf; see also Jindrich Kloub, "White paper on damage actions for breach of the EC antitrust rules: Plea for a more holistic approach to antitrust enforcement", European Competition Journal 5, no. 2 (2009): 515-547.

${ }^{28}$ European Parliament, Resolution of 26 March 2009 on the White Paper on damages actions for breach of the EC antitrust rules (2008/2154(INI)), https://www.europarl.europa.eu/sides/getDoc. do?pubRef=-//EP//NONSGML+TA+P6-TA-2009-0187+0+DOC+PDF+V0//EN.

${ }^{29}$ On that problem, see Judgment of 14 June 2011, Pfleiderer AG v. Bundeskartellamt, C-360/09, EU:C:2011:389, paragraphs 30-32, and Judgment of 6 June 2013, Bundeswettbewerbsbehörde v. Donau Chemie AG and Others, C-536/11, EU:C:2013:366; see also Sven Völcker, "Case C-360/09, Pfleiderer AG v. Bundeskartellamt, Judgment of the Court of Justice (Grand Chamber) of 14 June 2011, nyr", Common Market Law Review 49 (2012): 699, and Caroline Cauffman, "Access to leniency-related documents after Pfleiderer”, World Competition 34, no. 4 (2011): 597-615.

${ }^{30}$ See, on fault, Katri Havu, "Fault in EU competition law damages claims", Global Competition Litigation Review 8, no. 1 (2015): 1-13.

${ }^{31}$ See, indeed, Recital 5, 2014 Directive.

${ }^{32}$ For an analysis on how private enforcement contributes to public market regulation, see Sara Landini, "Private enforcement and market regulation", Market and Competition Law Review 2, no. 2 (2018): 47-71.
} 
law and are complemented by alternative avenues of redress, such as consensual dispute resolution and public enforcement decisions that give parties an incentive to provide compensation". ${ }^{33}$ The Directive continues by stating that "to ensure effective private enforcement actions under civil law and effective public enforcement by competition authorities, both tools are required to interact to ensure maximum effectiveness of the competition rules". ${ }^{34}$ Effectiveness of competition law provisions presupposes some kind of deterrence, coupled with the right to full compensation. The Directive's provisions and presumptions included therein aim to balance those different objectives.

At the same time, however, the Directive does not aim to impose additional deterrence mechanisms on businesses just for the sake of deterrence. The Directive indeed states that its principal objective is to give victims the right to full compensation. Full compensation implies a person who has suffered harm being placed in the position in which they would have been had the infringement of competition law not been committed. It therefore covers the right to compensation for actual loss and for loss of profit, plus the payment of interest. According to the Directive, it shall not lead to overcompensation, whether by means of punitive, multiple or other types of damages. ${ }^{35}$ In that understanding, the deterrent effect of the Directive is limited only to the threat that any individual having incurred damages may introduce, potentially on top of public enforcement sanctions, actions for the award of compensatory damages.

The 2014 Directive essentially wants to stimulate private enforcement as a complement to public enforcement. Although it requires Member States to recognise both stand-alone and follow-on actions, the latter seem to be preferred. ${ }^{36}$ The Directive imposes an irrebuttable presumption that national competition authorities' infringement decisions are also a proof of fault before the courts of that Member State. ${ }^{37}$ It establishes a presumption of harm and recognises indirect purchaser standing. ${ }^{38}$ Those presumptions and recognitions give individuals new rights and possibilities

\footnotetext{
${ }^{33}$ Recital 5, 2014 Directive.

${ }^{34}$ Recital 6, 2014 Directive.

${ }^{35}$ Article 3, 2014 Directive.

${ }^{36}$ Ulf Bernitz, "Introduction to the Directive on competition damages actions", in Harmonising EU Competition Litigation: The New Directive and Beyond, eds. Maria Bergström, Magnus Strand and Marios Iacovides (Oxford: Hart, 2016), 8.

${ }^{37}$ Article 9, 2014 Directive.

${ }^{38}$ Articles 12-14 and 17(2), 2014 Directive.
} 
to target infringing undertakings directly ${ }^{39}$, yet have also been framed in terms of additional deterrence instruments. A reasonable undertaking abiding by the law may be discouraged from entering in anticompetitive agreements or decision-makings when the potentiality of damages actions will be added to public enforcement. It is in that spirit that the Directive grants and conditions individuals' rights to claim damages.

The Directive's provisions essentially focus on introducing presumptions of fault, of harm, on determining how individuals can have access to certain evidence and how liability will be distributed between different infringers. ${ }^{40}$ In that context, the topic of collective actions - so-called class or group actions - has also popped up. ${ }^{41}$ Collective actions refer to a series of legal remedies that allow representatives to file claims for damages on behalf of a certain group of victims and to be awarded damages for the whole of that group..$^{42}$ Those actions are well-known in the United States ${ }^{43}$, yet many EU Member States have some kind of collective action remedy on their books as well ${ }^{44}$, applicable across all fields or tailored to the specifics of competition law. Although different types of group actions exist, one distinguishes generally between opt-out and opt-in actions. Opt-out implies that an action is introduced on behalf of the whole group of victims - even those that may not be aware of the action - essentially barring them from introducing an individual action unless they explicitly state not to be willing to be part of the group action. Opt-in refers to members of

\footnotetext{
${ }^{39}$ Pieter Van Cleynenbreugel, "The presumption of harm and its implementation in the Member States' legal orders", in EU Competition Litigation: Transposition and First Experiences of the New Regime, eds. Magnus Strand, Vladimir Bastidas and Marios Iacovides (Oxford: Hart, 2019), 206207.

${ }^{40}$ For a good overview, see Niamh Dunne, "Courage and compromise: The directive on antitrust damages", European Law Review 40, no. 4 (2015): 581-587.

${ }^{41}$ See, for general background, Christopher Hodges, The Reform of Class and Representative Actions in European Legal Systems. A New Framework for Collective Redress in Europe (Oxford: Hart, 2008), 324.

${ }^{42}$ The European Commission refers to those types of actions as collective redress mechanisms, see European Commission, Recommendation of 11 June 2013 on common principles for injunctive and compensatory collective redress mechanisms in the Member States concerning violations of rights granted under Union Law, [2013] O.J. L201/60, https://eur-lex.europa.eu/legal-content/EN/TXT/ $\mathrm{PDF} /$ ?uri=CELEX:32013H0396\&from=EN.

${ }^{43}$ In the realm of competition law, see e.g. American Bar Association, Antitrust Class Actions Handbook, Second Edition (Washington: ABA Publishing, 2018), 388.

${ }^{44}$ For a recent report, see the October 2018 Report requested by the European Parliament entitled Collective Redress in the Member States of the European Union, http://www.europarl.europa.eu/ RegData/etudes/STUD/2018/608829/IPOL_STU(2018)608829_EN.pdf.
} 
the group explicitly (or implicitly) having to accept being included in the group action. ${ }^{45}$ Those Member States that have it have often chosen not to take the US opt-out model, but rather an opt-in model. ${ }^{46}$ In the same way, recent proposals for EU collective actions in the realm of EU consumer protection law go in that same direction ${ }^{47}$ Given the large variety of group action mechanisms, and despite their potential in terms of deterrence, the Commission decided not to impose this type of action in its 2014 private Damages Directive. ${ }^{48}$ Member States thus remained free to decide whether or not to introduce this possibility within the realm of EU competition law. ${ }^{49}$

\section{c. Corrective and/or restorative justice?}

A question that has remained largely implicit in the abovementioned debate concerns the question of what kind of compensatory justice the Directive seeks to attain. To answer that question, it is important to distinguish corrective from more general restorative justice understandings. Corrective justice refers to Aristotle's idea that if one party has committed and another one has suffered that (transactional) injustice ${ }^{50}$, equality needs to be restored. ${ }^{51}$ Equality in that understanding consists in each person being given that which she/he is entitled to relatively to another person. Although not all persons are fully equal, societies are indeed (to

\footnotetext{
${ }^{45}$ On that difference, see Zygimantas Juska, "Obstacles in European competition law enforcement: A potential solution from collective redress”, European Journal of Legal Studies 7, no. 1 (2014): 143. ${ }^{46}$ See the October 2018 Report of the European Parliament; Portugal offers an interesting exception, see Sofia Oliveira Pais, "A first look at the Portuguese Act 23/2018 transposing the private enforcement Directive", in Transposition and First Experiences of the New Regime, eds. Magnus Strand, Vladimir Bastidas and Marios Iacovides (Oxford: Hart, 2019), 74.

${ }^{47} \mathrm{See}$, in that regard, European Commission, Proposal for a Directive of the European Parliament and of the Council on representative actions for the protection of the collective interests of consumers, and repealing Directive 2009/22/EC, COM2018(184) final, https://eur-lex.europa.eu/legal-content/ EN/TXT/HTML/?uri=CELEX:52018PC0184\&from=EN.

${ }^{48}$ Recital 13, 2014 Directive.

${ }^{49}$ Also leaving room for manoeuvre for Member States. On manoeuvring room, more generally, see Anna Piszcz, "Room for manoeuvre for Member States: Issues for decision on the occasion of the transposition of the Damages Directive", Market and Competition Law Review 1, no. 1 (2017): 81-109.

${ }^{50}$ See Aristotle, Nicomachean Ethics, Book IV, available in English at http://classics.mit.edu/ Aristotle/nicomachaen.4.iv.html. See also Anton-Hermann Chroust and David L. Osborn, "Aristotle's conception of justice", Notre Dame Law Review 17, no. 2 (1942): 140.

${ }^{51}$ Ernest J. Weinrib, "Corrective justice in a nutshell", The University of Toronto Law Journal 52, no. 2 (2002): 349 .
} 
be) organised in such a way that everyone is given a relative position in relation to each other. That starting position would constitute the baseline against which equality is measured. If a person gets less than their baseline position because another person harms them, the injustice consisting in this kind of baseline inequality would have to be corrected..$^{52}$ Corrective justice consists in restoring the initial relative equality between two persons by depriving one party of the gain he/she obtained at the expense of the other party. ${ }^{53}$ In doing so, the equilibrium in the transactional relationship between those parties can be corrected and restored. ${ }^{54}$ The injustice consisting in the inequality caused by the action of one party would be corrected indeed. One can think of many ways to correct such inequalities, yet compensation is the most important way of obtaining that result. Restoration of the baseline equality between different businesses or individuals is made possible by quantifying and awarding monetary compensations to victims of anticompetitive behaviour.

In contrast with corrective justice, restorative justice refers to a series of processes aimed not only or necessarily at correcting wrongs done to an individual, but to a series of processes aimed at restoring the disturbed equilibrium, both from a societal and an individual point of view. It envisages a wider array of restorative mechanisms and processes than a corrective justice approach does, the latter essentially focusing only on compensation. When corrective justice is necessarily backward-looking, restorative justice looks forward to ensure future infringements no longer take place and harmony between the different societal participants is restored. ${ }^{55}$ Restorative justice processes may encompass compensation as well, but also envisage alternative ways beyond restoring baseline equality; they are a more forward-looking way of justice, ensuring that similar disturbances to baseline equality no longer take place in the future.

It follows from this basic distinction made between corrective and restorative justice that the ambitions of the 2014 Directive essentially remain limited to a compensatory corrective justice approach. The main focus of the Directive is to restore the baseline equality and to compensate victims

\footnotetext{
${ }^{52}$ Weinrib, “Corrective justice": 349-350.

${ }^{53}$ Weinrib, "Corrective justice": 350.

${ }^{54}$ For an account linking corrective justice and reciprocity, see Thomas C. Brickhouse, "Aristotle on corrective justice", The Journal of Ethics 18, no. 3 (2014): 187-205.

${ }^{55}$ See John Braithwaite, "The fundamentals of restorative justice”, in A Kind of Mending: Restorative Justice in the Pacific Islands, ed. Sinclair Dinnen et al. (Canberra: ANU Press, 2003), 35.
} 
of anticompetitive behaviour by awarding them monetary damages. At the same time, however, the Directive also allows for consensual dispute mechanisms to be set up at Member State level, yet, within the spirit of the Directive, those mechanisms are supposed to serve the sole purpose of bringing an out-of-court settlement of monetary claims grounded in the action for damages. ${ }^{56}$

It is submitted that this consensual dispute resolution mechanism envisaged by the 2014 Directive opens the door towards more restorative justice-inspired processes as described above. Recital 48 of the Directive states that "[a]chieving a 'once-and-for-all' settlement for defendants is desirable in order to reduce uncertainty for infringers and injured parties. Therefore, infringers and injured parties should be encouraged to agree on compensating for the harm caused by a competition law infringement through consensual dispute resolution mechanisms, such as out-ofcourt settlements (including those where a judge can declare a settlement binding), arbitration, mediation or conciliation. Such consensual dispute resolution should cover as many injured parties and infringers as legally possible".

In practice, however, the Directive still conditions those procedures fundamentally within the logic of the award of compensatory damages. According to Article 18 of the Directive, Member States shall ensure that the limitation period for bringing an action for damages is suspended for the duration of any consensual dispute resolution process. The suspension of the limitation period shall apply only with regard to those parties that are or were involved or represented in the consensual dispute resolution. Member States have to ensure that national courts seized of an action for damages may suspend their proceedings for up to two years where the parties thereto are involved in consensual dispute resolution concerning the claim covered by that action for damages. Consensual dispute settlements envisaged by the Directive appear to only be limited to determining, quantifying and eventually granting an amount of damages by way of compensation to the claimant of a damages action. That is evidenced by Article 19 of the Directive, which confirms that following a consensual settlement, the claim of the settling injured party is reduced by the settling co-infringer's share of the harm that the infringement of competition law inflicted upon the injured party. The rest of the share is in principle to be obtained

\footnotetext{
${ }^{56}$ Recital 48, 2014 Directive.
} 
from the non-settling parties. ${ }^{57}$ On top of that, a competition authority may consider compensation paid as a result of a consensual settlement and prior to its decision of imposing a fine to be a mitigating factor. ${ }^{58}$

As evidenced by those provisions, the setup of consensual dispute settlement mechanisms is largely left to Member States. The Directive, for its part, only considers the compensatory aspects of those consensual dispute settlements. By focusing directly and only on the award of damages by means of compensation, the Directive implicitly risks to downplay the importance of other restorative justice mechanisms or tools. As such, the Directive's corrective justice focus remains firmly embedded in the idea that compensating harmed individuals only amounts to paying them a sum of money in compensation. At the same time, however, the fact that attention is paid to consensual dispute settlements would seem to indicate that the EU legislature is, at least, not closing down completely on possibilities for restorative justice in the realm of EU competition law. It is this opening that will be used to further explore whether a more institutionalised framework for promoting restorative justice in this field could be set up as a complement to the current public-private enforcement dichotomy.

\section{Taking restorative justice seriously? A proposal to set up antitrust "trust funds"}

If one takes the claim that the Damages Directive contains at least some openness to more structured restorative justice processes seriously, the current setup and structure of that Directive can hardly be considered sufficient. Although private damages actions partially contribute to individuals' sense of justice, taking restorative justice seriously and overcoming the gaps identified in the previous part while doing so requires a more focused and alternative enforcement approach.

This part of the article proposes such an approach, after revisiting the basics of restorative justice (a.). It will propose the establishment and setup of mixed public-private "antitrust trust funds". Antitrust trust funds would be publicly regulated private associations set up with the specific purpose of rendering restorative justice processes more available and visible to victims and offenders of competition law infringements. A form of consensual dispute settlement overseen by public authorities, funds could

\footnotetext{
${ }^{57}$ Article 19(2), 2014 Directive.

${ }^{58}$ Article 18(3), 2014 Directive.
} 
bring the advantages of collective actions before the courts, yet also alleviating the disadvantages that type of claims may bring. It deserves to be clarified, at this stage, that the proposal to set up antitrust trust funds is just one possible way to enhance restorative justice processes in EU competition law enforcement. This proposal should therefore and above all be understood as a means to stimulate academic and policy debates on how to move those concerns forward within the current EU competition law enforcement framework.

After explaining how the setup of antitrust trust funds could be envisaged (b.), it will distinguish the setup of trust funds from collective actionbased settlement systems that would attain similar objectives (c.). However, even if that idea were pushed forward, limited legal yet significant practical limits would remain in setting up such trust funds as a matter of EU law (d.). Nevertheless, considering this option at least as an alternative or complement to class actions would thus seem a road worth taking at this stage, if and to the extent that more focused attention on restorative justice is indeed an ambition or objective of EU competition law enforcement.

\section{a. Revisiting restorative justice}

Within the field of criminal justice, the whole of those techniques are often called restorative, rather than corrective justice. Attention to the processes and conditions of restorative justice has given rise to a sub-field in criminal justice scholarship exploring other forms of correction and rendering justice. This kind of restorative justice has been defined by John Braithwaite, one of its most important scholars, as "a process in which all the stakeholders affected by an injustice have the opportunity to discuss the consequences of the injustice and what might be done to put them right. This is a process conception of restorative justice by which what is to be restored is left open. Rather, the form of restoration of victims, of offenders and of communities that count are those found to be important in such a restorative justice process. Beyond the process conception, there is also a values conception of restorative justice. The key value is that because injustice hurts, justice should heal". ${ }^{59}$

\footnotetext{
${ }^{59}$ John Braithwaite, "The fundamentals of restorative justice", in A Kind of Mending: Restorative Justice in the Pacific Islands, ed. Sinclair Dinnen et al. (Canberra: ANU Press, 2003), 35. A similar definition is used in point 3 of the Council of Europe's October 2018 non-binding Recommendation CM/Rec(2018)8 of the Committee of Ministers to Member States concerning restorative justice in criminal matters, http://search.coe.int.
} 
This general description contains three elements important in the context of competition law enforcement as well. First, restorative justice concerns a variety of processes. Those processes can vary between very formal and legalised processes, forming part of institutionalised mediation efforts that are obligatory prior to a sentence being imposed ${ }^{60}$ and most informal meetings between victims and offenders, often operating in the shadow of the traditional justice system. ${ }^{61}$ The idea of restorative justice covers a wide array of processes that can include, yet also significantly go beyond awarding monetary damages to victims of infringements of legal provisions. Second, those processes involve all stakeholders concerned. That means that in principle, restorative justice is premised upon the idea of dialogue between all those involved in the violation of legal provisions. Of course, that concerns above all the victim, yet also the community or society at large. In order to institutionalise a process of restorative justice, third parties can be called upon to take part in restorative justice conversations. Third, conversations are central to the idea of restorative justice. ${ }^{62}$ In order to resolve baseline inequalities caused by an infringer, a process of dialogue has been set up between the victim and the offender, and, if necessary, other members of a society. ${ }^{63}$ Such dialogues - or conferences ${ }^{64}$ - can take the format of a dialogue between two private individuals, overseen and guided by a mediator, advanced settlement talks between a prosecuting service and an offender of laws that go against public order (such as competition law provisions) or more structured talks taking place between victims, offenders and the community in which they are/were active. ${ }^{65}$ One of the essential elements of restorative justice is the fact that a direct dialogue takes place. Without such a dialogue, reaching a restorative solution

\footnotetext{
${ }^{60}$ See, for that conception, Andrew Brady Spalding, "Restorative justice for multinational corporations”, Ohio State Law Journal 76, no. 2 (2015): 397.

${ }^{61}$ See points 15-20 of the Council of Europe's October 2018 Recommendation.

${ }^{62}$ Howard Zehr, ChangingLenses: Restorative Justice for Our Times, Second Edition (Harrisonsburg: Herald Press, 2015), 338.

${ }^{63}$ Giuseppe Maglione, “Discursive fields and subject positions: Becoming 'victim', 'offender' and 'community' in restorative justice”, Restorative Justice 2, no. 3 (2014), 327-348.

${ }^{64}$ Braithwaite, "The fundamentals of restorative justice", 40.

${ }^{65}$ See, for that variety, Emmanuela Biffi and Tim Chapman, Restorative Justice Responses to Conflicts in Intercultural Settings: Practice Guidelines (Leuven: European Forum for Restorative Justice, 2015), http://alternativefilms.euforumrj.org/e-books/.
} 
capable of bringing the justice equilibrium back would appear difficult in practice. ${ }^{66}$

Another essential element of this dialogue is that both victim and offender have to be willing to engage in such a dialogue ${ }^{67}$ If one of the parties refuses to do so, restorative justice potential is deemed limited and restorative justice processes are not likely to be initiated. ${ }^{68}$

Understood in that sense, restorative justice has given rise to the organisation of numerous types of conferences - with varying degrees of success - in relation to particular types of crimes, including small property crimes $^{69}$, juvenile crimes ${ }^{70}$ and domestic violence, ${ }^{71}$ among other fields. In each particular context, restorative justice processes serve to contribute to restoring a harmful situation by means of a structured and developed dialogue. The outcomes of the dialogue - restoration of some kind - are not always set in stone. At times, acknowledging wrongdoing on behalf of the offender and an apology may be sufficient for the victim. In other contexts, a particular public service obligation undertaken by the offender or the payment of compensatory damages of monetary or other nature can also be envisaged. The restorative justice process is characterised by a flexibility that allows for different types of remedies to be taken into consideration as outcomes of that process.

\footnotetext{
${ }^{66}$ See David K. Androff, "Reconciliation in a community-based restorative justice intervention", Journal of Sociology and Social Welfare 39, no. 4 (2012): 73-96.

${ }^{67}$ See point 15 of the Council of Europe's October 2018 Recommendation. In the same way, the 2012 EU Victim Rights Directive (Directive 2012/29/EU of the European Parliament and of the Council of 25 October 2012 establishing minimum standards on the rights, support and protection of victims of crime, and replacing Council Framework Decision 2001/220/JHA, [2012] O.J. L315/57) is premised on the same principle. See also Katrien Lauwaert, "Restorative justice in the $2012 \mathrm{EU}$ Victims Directive: A right to quality service, but no right to equal access for victims of crime", Restorative Justice 1, no. 3 (2013): 414-425.

${ }^{68}$ See also Carie Menkel-Meadow, "Restorative justice: What is it and how does it work?", Annual Review of Law and Social Science no. 3 (2007): 10.1-10.27.

${ }^{69}$ Jo-Anne Wemmers, "Restorative justice for victims of crime: A victim-oriented approach to restorative justice", International Review of Victimology, 9 (2002): 49.

${ }^{70}$ Heather Strang, "Justice for victims of young offenders: The centrality of emotional harm and restoration", in Restorative Justice for Juveniles. Conferencing, Mediation and Circles, ed. Allison Morris and Gabrielle Maxwell (Oxford: Hart, 2001), 183.

${ }^{71}$ John Braithwaite and Heather Strang, "Restorative justice and family violence", in Restorative Justice and Family Violence, ed. John Braithwaite and Heather Strang (Cambridge: Cambridge University Press, 2002), 3-4.
} 
Although predominantly developed in the realm of criminal justice, business regulation in general and competition $\mathrm{law}^{72}$ in particular have also been contemplated or implemented. ${ }^{73}$ It is remarkable, however, that restorative justice processes in the context of EU competition law enforcement have been rather limited in scope and scale. When the issue of restorative justice pops up, discussions centre mainly on commitments in public enforcement, where a dialogue between the public enforcement authority and the potential offender results in a promise not to keep infringing competition laws in the future. As a result, no infringement or sanction is established formally under competition law. ${ }^{74}$ Although this process closely resembles restorative justice ambitions outlined here, two marked differences can also be pointed at. First, commitment procedures do not involve all stakeholders. Only the public enforcement authority representing the public interest enters into a dialogue with the potential offender. Individuals harmed by the infringement only marginally have a right to make their voice heard - through the intermediary of the public authority. As a result, the restorative discussion is very limited in nature. Second, the outcome of commitment negotiations does not necessarily result in a satisfactory restoration of baseline equality for all those harmed by the (potential) competition law infringement. Quite on the contrary, a commitment decision implies stopping anticompetitive behaviour for the future, but does not address the harm already previously inflicted by that very behaviour. ${ }^{75}$ Individuals harmed by such behaviour would have to rely on the private damages actions' remedy to obtain compensation for the harm incurred.

\footnotetext{
${ }^{72}$ See most notably in Australian competition law, Christine Parker, "Restorative justice in business regulation? The Australian Competition and Consumer Commission's use of enforceable undertakings", Modern Law Review, 67, no. 2 (2004): 204-246; Karen Yeung, Securing Compliance: A Principled Approach (Oxford: Hart, 2004), 307. See also John Braithwaite, "Restorative justice for banks through negative licensing”, British Journal of Criminology 49, no. 4 (2009): 439-450.

${ }^{73}$ John Braithwaite, Restorative Justice and Responsive Regulation (Oxford: Oxford University Press, 2002), 336.

${ }^{74}$ See Article 9 of Council Regulation 1/2003 of 16 December 2002 on the implementation of the rules on competition laid down in Articles 81 and 82 of the Treaty, [2003] OJ L 1/1. See, on that procedure, Rafael García Valdecasas and Aitor Montesa Lloreda, "A new life for commitment decisions under Article 9 of Regulation 1/2003? The aftermath of the ECJ Judgment of 29 June 2010 in Case C-441/07P, Commission v. Alrosa", in Today's Multi-Layered Legal Order: Current Issues and Perspectives, ed. Tristan Baumé et al. (Paris: Zutphen, 2011), 99-100.

${ }^{75}$ See also Axel Gautier and Nicolas Petit, "Optimal enforcement of competition policy: The commitments procedure under uncertainty”, https://ssrn.com/abstract=2509729.
} 


\section{b. "Antitrust trust funds": an alternative intermediate structure promoting restorative justice?}

To the extent that consensual dispute settlement mechanisms would seem possible and even desirable as a matter of EU competition law enforcement, this article would like to propose the establishment of "antitrust trust funds" as a way forward in enhancing the restorative justice potential of EU competition law enforcement. It is indeed submitted that those funds could embrace and render possible both individual and collective consensual settlements in a more informal way, having a wider series of restorative justice powers at their disposal. Although setting up such funds may constitute a way forward, different important questions need to be addressed as to the powers and governance of those funds. As this paper only explores the feasibility and possibility of such trust fund solution, it does not answer all those questions, but rather chooses to flag them as issues waiting to be resolved once the choice for trust funds has been made...

In referring to "antitrust trust funds", we refer to associations, either at EU or Member State level, which do not have a profit-making purpose. Those associations, which can have legal personality or not, would be set up with the specific purpose of managing restorative processes linked with the infringement of EU (and national) competition law provisions. They would be independent from government authorities, enforcement bodies and the judiciary. As independent bodies, they would be governed, above all, by competition law and restorative justice experts, yet remain accountable to and regulated by public institutions that would control their activities. To the extent that those bodies contribute to advancing restorative justice and victims' sense of justice confronted with competition law infringements, it could be expected that public authorities could bear the costs of setting up and funding the operations of those trust funds. To distinguish them from public authorities, they could take the format of a particular publicly-funded or endorsed non-profit association in so far as the relevant legal provisions allow for this.

At first sight, this type of setting closely resembles the charitable trust figure under English law. In that configuration, a separate entity is set up for a particular public - charitable - purpose. The entity is private in nature, having its own staff and resources which are allocated to the promotion or protection of a particular charity. ${ }^{76}$ A government body, the

\footnotetext{
${ }^{76}$ See James E. Penner, The Law of Trusts (Oxford: Oxford University Press, 2019), 490.
} 
Charity Commission in England and Wales, oversees whether the trust is only used for this purpose and whether and how the trust's assets are used in a correct way, and intervenes when necessary. ${ }^{77}$ In addition, the courts can intervene to review the Commission's decisions. ${ }^{78}$ The difference between antitrust trust funds envisaged here and charitable trusts is that the latter emerge from private initiatives to invest and contribute to certain charitable activities. The proposal made here considers the trust funds being created by a public authority in order to advance the causes of consensual settlement and restorative justice and to offer a more nuanced private enforcement structure. To that extent, the operational costs (staff, infrastructure) would most likely be borne by public authorities rather than private donations, as is generally the case with charitable trusts.

As associations set up, the antitrust trust funds would manage the restorative process accompanying proclaimed or established competition law infringements. Here again, important choices would have to be made. The first question in that regard is whether any individual could appeal to them and be immediately entitled to a restorative conference, or whether the fund would need to bring together a group of victims prior to starting restorative justice processes. Given that the fund wants to present itself as an alternative to collective actions initiated by private and temporary associations or organisations, a wider and easier access to its services than through a class action should probably be envisaged. A related question would concern the relationship between the fund's intervention and existing public enforcement mechanisms. As instances of consensual dispute settlement, it can be expected that those funds would play a follow-on role: they would only come into play once an infringement of competition law has been established or once it is likely that an infringement has taken place and the offender is willing to engage in a dialogue with those harmed by that infringement. As such, intervention by the antitrust trust fund would require at least some proof, to a required legal standard, that a potential competition law infringement has taken place. Nevertheless, absent such proof, it is also perfectly imaginable that an offender and a victim would like to engage in restorative deliberations, rather than to take

\footnotetext{
${ }^{77}$ See https://www.gov.uk/government/organisations/charity-commission.

${ }^{78}$ The appeal takes place before a first-tier tribunal, see https://www.gov.uk/courts-tribunals/firsttier-tribunal-general-regulatory-chamber; against that tribunal's decision, an appeal can be made before an upper tribunal (Tax and Chancery Chamber), see https:/www.gov.uk/courts-tribunals/ upper-tribunal-tax-and-chancery-chamber.
} 
the case to court in a stand-alone private damages action. A possibility for individuals, or a sufficiently representative group of individuals, to request restorative justice deliberations in the absence of any public enforcement to be started could be offered in that regard as well. Whatever the choices made in that respect, the fund would have to be accessible for individuals and offenders willing to start restorative justice dialogues.

In terms of mandates and powers conferred on the trust funds, the name "trust fund" may be a bit misleading. In common legal parlance, trust fund refers to a framework for managing a sum of money and seeing that this money is spent in a correct manner. ${ }^{79}$ The role of antitrust trust funds could encompass this; yet, it is also much wider than just managing money. Indeed, the very purpose of those funds would be to offer a wider array of restorative justice options, including going beyond monetary compensation. Their primary role would be to offer a basic structure for consensual dispute settlements in the realm of EU competition law. From that point of view, the organisation of restorative justice conferences between individual or groups of victims and (suspected) offenders would be the first task. Fund managers or representatives would be asked to take on the role of a restorative justice mediator or overseer, structuring and guiding the dialogue between the different parties if necessary. That fund-associated mediator would also engage in preliminary conversations with both offender and victim to question whether a restorative conference could be set up indeed and what the expectations of both sides are. Following those early contacts, the fund representatives would actively have to call on other stakeholders to express their interest and give those stakeholders the opportunity to be heard. As such, individual victims and representatives of society at large can all be called upon to engage in a restorative dialogue, structured and overseen by the fund. At the outcome of such dialogue, appropriate redress mechanisms can be envisaged. It is in that context that different options should be left to the fund to explore and propose. One solution could consist in a formal apology and acknowledgement of wrong (potentially accompanied by a promise from victims not to claim monetary damages later), a decision to restore the damage done by doing something for society at large, or a decision expressing willingness to compensate all victims. In the last situation, it could be envisaged that the offender(s) donate(s) a sum of money to the trust fund, which will

\footnotetext{
${ }^{79}$ See https://www.merriam-webster.com/legal/trust $\% 20$ fund\%20doctrine.
} 
be responsible for distributing it to known and potentially still unknown competition law victims or to causes closely associated with the competition law violation which took place. The fund would be tasked with managing those funds and overseeing their distribution and it could be expected that EU-wide distribution guidelines or principles on how to distribute fund revenues to particular victims would be developed in that regard. Just like in private damages actions, the quantification of harm and the determination of the amount of compensation promises to be a complicated exercise. The flexibility of restorative justice approaches could perhaps tolerate more flexibility in the distribution of fund revenues as well. That being the case - as some victims may not want money as compensation - it has to be ensured that fundamental legal principles, such as equal treatment and legal certainty, will also be respected by those funds. An overseeing body similar to the Charity Commission in England would have to play a fundamental role in ensuring respect for such principles.

Agreements concluded in the context of the fund's activities could be subsequently formalised by either an administrative or judicial decision, resulting in judges retaining the final authority. It goes without saying that damages awarded within that context would then result in a restriction on the ability to claim monetary damages on the basis of the 2014 Directive.

In terms of governance, it could be imagined that the "antitrust trust fund" would be governed by a board of overseers and a management board comprising experts in restorative justice and competition law and would be tasked, in the first place, with the organisation of restorative conferences between offender and victims. If it turns out both offender and victims want to engage in such conversations to talk about the damages done and the repairs that could be envisaged, the fund could formally start up contacts, engage in communications seeking to find other victims and start up the restorative conference. The board of overseers could then be asked to validate proposed decisions and put them into operation. A government department or a judge could be tasked with overseeing their implementation, intervening whenever necessary. In any case, a judge would have the final authority to deal with claims regarding misapplication of the law by trust fund authorities or by overseeing bodies.

The abovementioned reflections demonstrate that it is not entirely inappropriate to envisage a structure in which different restorative justice initiatives could be embedded. As the European Union competition law enforcement system is characterised by a strong focus on public enforcement, it 
would not seem entirely inappropriate to allow public authorities to play a leading role in setting up more developed restorative justice-focused arrangements as well. Antitrust trust funds, although private associations, would be sponsored by public authorities and would allow for restorative justice values to be firmly and directly available to those seeking justice after being confronted with competition law violations.

\section{c. Antitrust trust funds and collective action-based settlements: similarities and differences}

At first sight, the proposal to design antitrust trust funds closely resembles a consensual dispute settlement mechanism currently in the process of being deliberated in the realm of EU consumer law. On 11 April 2018, the European Commission decided to propose a new deal for consumers, involving the replacement of a 2009 Directive requiring Member States to introduce the remedy of injunction ${ }^{80}$ by a Directive imposing the setup of collective or class- actions in this field of law. Such actions can be introduced by a so-called qualified entity representing consumers' interests. ${ }^{81}$ Qualified entities have to be non-profit entities, either created ad hoc for the purpose of one collective action or more stable organisations in accordance with national law. They need to have a sufficient amount of financial resources and rules in place that avoid third parties having an influence on their actions. ${ }^{82}$ Those entities may start injunction or compensatory actions in court on behalf of a group of consumers, who may be explicitly required to join the action. ${ }^{83}$ Although court-centred, the Directive also provides for out-of-court settlement opportunities. According to Article 8 of the proposed Directive, Member States may provide that a qualified entity and a trader who have reached a settlement regarding redress for consumers affected by an allegedly illegal practice of that trader can jointly request a court or administrative authority to approve it. Such a request should be admitted by the court or administrative authority only if there is no other ongoing representative action in front of the court or administrative authority of the same Member State regarding the same trader

\footnotetext{
${ }^{80}$ EC, Proposal for a Directive on representative actions (hereafter 2018 Commission proposal).

${ }^{81}$ Directive 2009/22/EC of the European Parliament and of the Council of 23 April 2009 on injunctions for the protection of consumers' interests (Codified version), [2009] O.J. L110/30.

${ }^{82}$ Articles 4 and 9, 2018 Commission proposal.

${ }^{83}$ Article 6 (1), final sentence, 2018 Commission proposal: A Member State may require the mandate of the individual consumers concerned before a declaratory decision is made or a redress order is issued.
} 
and regarding the same practice. A settlement can take place either on the initiative of the qualified entity and the trader or on request of the court or the administrative authority overseeing the process. ${ }^{84}$ In the latter case, the settlement has to be reached within a certain time limit. Failure to do so will result in the collective action being continued. ${ }^{85}$ The court or administrative authority shall assess the legality and fairness of the settlement, taking into consideration the rights and interests of all parties, including the consumers concerned ${ }^{86}$ If that is the case, they will declare the settlement binding. On top of that, individual consumers will have to decide explicitly whether they accept to be bound by the settlement. In case they do not, they can continue or lodge an individual action before the Member States' courts. ${ }^{87}$ In terms of redress, the Directive provides for the following remedies to be accepted or proposed: compensation, repair, replacement, price reduction, contract termination or reimbursement of the price paid, as appropriate. ${ }^{88}$ The proposal has subsequently been taken up by the Council and the European Parliament. In March 2019, the Parliament reached an agreement, transmitting matters to the Council, which will likely take a position later that year. According to the revised proposal approved by the European Parliament, qualified entities are to be called qualified representative and the settlement is to be made binding on all consumers, deleting the exception that consumers can choose not to accept the settlement. ${ }^{89}$ At the time of writing, it remains to be seen to what extent the Council will propose additional modifications.

At first sight, the settlement procedure put in place in this related field of EU law bears significant similarities with the antitrust trust fund proposals made here. A particular entity can engage in out-of-court settlements with a (potential) offender, resulting in a variety of remedies to be proposed. A court or supervisory authority can declare, in a subsequent stage, the settlement binding on all consumers. A settlement can end the collective action, or at least suspend it. In addition, the Directive does not interfere

\footnotetext{
${ }^{84}$ Article 8(2) 2018 Commission proposal.

${ }^{85}$ Article 8(3) 2018 Commission proposal.

${ }^{86}$ Article 8(4) 2018 Commission proposal.

${ }^{87}$ Article 8(6) 2018 Commission proposal.

${ }^{88}$ Article 6(1) 2018 Commission proposal.

${ }^{89}$ See http://www.europarl.europa.eu/doceo/document/TA-8-2019-0222_EN.html?redirect for the text approved by the European Parliament.
} 
with the public enforcement powers of Member States' authorities, which have been subject to a different, yet related legislative proposal. ${ }^{90}$

Despite those similarities, two major differences remain between this system and the antitrust trust funds proposed here. First, the qualified representatives acting in collective settlement procedures can be associations created for only a limited duration and by representative private organisations. The proposal to establish antitrust trust funds would require some public intervention in the setup and organisation of those funds, in order to ensure their capacity to act as intermediaries in bringing justice to private claimants or groups of private claimants in a more informal way and with a publicly-structured institutional framework that allows varieties of private enforcement to take place. Second, the Directive allows for a variety of redress possibilities to remain in place, yet also and overall limits those to direct or indirect monetary compensations. The powers of the antitrust trust funds to engage in restorative justice dialogues and conferences would include, yet also go beyond, direct or indirect monetary compensation. As such, the funds' powers would be more extensive than the possibilities to settle envisaged in the proposed collective action Directive in this field. Despite those differences, the EU's clear ambition to have qualified representatives settle matters in a somewhat restorative justice-oriented way demonstrates at least that antitrust trust funds could be taken seriously as a way forward within the context of EU competition law enforcement as well.

\section{d. Legal and practical limits to setting up antitrust "trust funds"}

Although setting up antitrust trust funds may seem a possible way forward in enhancing restorative justice in the realm of private enforcement of EU competition law, the creation of such funds is likely to encounter both legal (i.) and practical (ii.) limits. Should a decision indeed be taken to put such mechanisms in place, discussions will likely focus on those limits.

\footnotetext{
${ }^{90}$ European Commission, Proposal for a Directive of the European Parliament and the Council amending Council Directive 93/13/EEC of 5 April 1993, Directive 98/6/EC of the European Parliament and of the Council, Directive 2005/29/EC of the European Parliament and of the Council and Directive 2011/83/EU of the European Parliament and of the Council as regards better enforcement and modernisation of EU consumer protection rules, COM2018(185) final, https://eur-lex. europa.eu/legal-content/EN/TXT/HTML/?uri=CELEX:52018PC0185\&from=EN.
} 


\section{i. Legal limits}

In terms of legal limits, one may wonder at which level trust funds would have to be set up, whether the EU would have a competence to set those funds up and whether the current 2014 Directive would allow for them.

First, the governance levels on which a trust fund would have to be set up need to be determined. One could imagine the Member States setting up such funds, and the EU also setting up an EU-wide fund for crossborder infringements of a sufficiently significant nature. At Member State level, it could be accepted that the EU requires Member States to set up such funds. After all, in other contexts, the EU has also requested Member States to set up independent public authorities tasked with overseeing EU law. ${ }^{91}$ It would not be surprising that, as a matter of principle, the EU can also require the setup of publicly funded private associations charged with restorative justice tasks. Even though the application of EU competition law is an exclusive competence conferred on the European Union ${ }^{92}$, EU law allows for the delegation of such powers to the Member States. ${ }^{93}$ At EU level, one could additionally imagine a body with EU legal personality to be set up in that regard, charged with restorative processes of a transnational nature. Although the EU has set up or delegated powers to private bodies in the past, the continuous impact of the Meroni doctrine and the limits it places on the powers of EU bodies ${ }^{94}$ may warrant a solution outside the EU legal framework. ${ }^{95}$ In that context, the creation of a European Stability Mechanism and a Single Resolution Board in the realm of the monetary and banking Union could serve as examples. ${ }^{96}$ In any case, when

\footnotetext{
${ }^{91}$ See, by way of example, in the field of data protection, Articles 51-52 of Regulation (EU) 2016/679 of the European Parliament and of the Council of 27 April 2016 on the protection of natural persons with regard to the processing of personal data and on the free movement of such data, and repealing Directive 95/46/EC (General Data Protection Regulation), [2016] O.J. L119/1.

${ }_{92}$ Article 3(1)(b) Treaty on the Functioning of the European Union.

${ }^{93}$ Pieter Van Cleynenbreugel, "Sharing powers within exclusive competences: Rethinking EU antitrust law enforcement”, Croatian Yearbook of European Law and Policy 12 (2016): 49-79.

${ }^{94}$ Merijn Chamon, EU Agencies. Legal and Political Limits to the Transformation of the EU Administration (Oxford: Oxford University Press, 2016), 432.

${ }^{95}$ Bruno De Witte, "Responses and the EU Legal order: Increased institutional variation or constitutional mutation?", European Constitutional Law Review 11, no. 3 (2015): 434-457.

${ }^{96}$ See, on those mechanisms, Federico Fabbrini, Economic Governance in Europe. Comparative Paradoxes and Constitutional Challenges (Oxford: Oxford University Press, 2016), 352; Gianno Lo Schiavo, The Role of Financial Stability in EU Law and Policy (The Hague: Kluwer, 2017), 300; Vestert Borger, The Transformation of the Euro: Law, Contract, Solidarity (Leiden University, PhD thesis, 2018).
} 
setting up a fund like this at the EU level, careful attention will have to be paid to the limits posited by the principle of conferral and the limits placed on delegation of powers in the EU legal order.

Second, it is believed that Articles 103 and 114 TFEU combined could serve as a legal basis for the setup of both Member States' and EU trust funds as well. This dual legal basis has been relied on for the 2014 Directive and could be used as a basis for further restorative justice-focused instruments as well. In that context, the EU legislator stated that "[a]s the differences in the liability regimes applicable in the Member States may negatively affect both competition and the proper functioning of the internal market, it is appropriate to base this Directive on the dual legal bases of Articles 103 and 114 TFEU". ${ }^{97}$ The same reasoning essentially works for any steps further to streamline private enforcement, consensual dispute settlement mechanisms and restorative justice initiatives within the framework of EU competition law.

Third, questions may also arise as to the compatibility of antitrust trust funds with the spirit of the 2014 Directive. With regard to that question, it is submitted that the Directive, by allowing for consensual dispute settlement mechanisms to be put in place, would essentially promote a more streamlined consensual dispute settlement mechanism as well. Given the way in which such systems are presently facilitated by Article 18 of the Directive, a more streamlined approach to them would certainly be compatible with the overall objectives of that Directive.

It follows from the foregoing that the setup of antitrust trust funds would as such encounter no significant legal problems from an EU law point of view. The only difficulty would be to set up an EU-wide trust fund; at Member State level, the creation of such funds could be demanded by means of EU secondary legislation, if the EU legislator (including the Member States) manages to reach an agreement on that point during legislative deliberations.

\section{ii. Practical limits}

In terms of practical limits that could hinder the operations of trust funds, their relationship with existing public and private enforcement mechanism is likely to raise several questions. Two main considerations deserve to be developed here.

\footnotetext{
${ }^{97}$ Recital 82014 Directive.
} 
First, the major practical limit to setting up "trust funds" would relate to the added value of such trust funds in terms of incentives. It is true that funds could give victims of anticompetitive behaviour a simpler and clearer venue through which they can try to seek and obtain compensation. At the same time, however, one can legitimately wonder why an undertaking having (potentially) infringed competition law would be willing to engage in restorative justice talks through a publicly established body. Although research on incentives in restorative justice suggests that perpetrators may be willing to do so out of shame when the initiative has been taken by one or more victims and appeal is made to their social responsibility ${ }^{98}$, it could also be imagined that undertakings would not be willing to engage in such more consensual type of dispute resolution without proper incentives to do so. From that perspective, it would not be unimaginable to envisage mechanisms pushing undertakings towards restorative dispute resolution. One could think of public enforcement sanctions being lowered if and to the extent that a willingness to engage in restorative justice is present or, inversely, to foresee higher fines for those undertakings refusing to engage in restorative practices. In the same way, the threat of higher damages awards absent restorative justice willingness may also be an additional trigger. In any case, when setting up mechanisms like the ones proposed here, incentivising infringing undertakings needs to be taken seriously.

Second, in addition to incentives for infringers to engage in restorative justice processes, there is the question as to what extent restorative justice initiatives are to relate to both existing public enforcement and private damages actions. In terms of the latter, the solution seems rather simple. The development of antitrust trust funds at national level would be a more coherent and streamlined way of setting up consensual dispute settlement mechanisms in compliance with Article 18 of the 2014 Directive. As such, the rule stated in there that limitation periods are suspended and that settled results have an impact on the amount of compensation that can be requested remain applicable indeed. What would be required, however, are rules establishing to what extent confessions and restorative proposals made in the context of restorative justice dialogues result in a loss of the right to file a claim for compensatory damages. Article 18 of the Directive gives some guidance in that regard, yet a more full-fledged consensual

\footnotetext{
${ }^{98}$ See, by way of example of a much larger body of literature, Tom Tyler, "Restorative justice and procedural justice: Dealing with rule breaking”, Journal of Social Issues 62 (2006): 321.
} 
restorative justice-oriented dispute settlement mechanism would require more detailed rules to be established. In the absence of such rules, offenders may not be willing to agree to restorative justice dialogues being initiated.

As far as public enforcement is concerned, it has to be emphasised that the antitrust trust funds aim to contribute to restorative justice for private individuals or for groups of individuals. As such, their activities essentially concern private enforcement. Nothing would seem to impede that, once the potentiality or presence of an infringement has become clear, victim and offender can decide to start up this process, in parallel with public enforcement. Just like with private damages actions, however, a framework will have to be put in place regarding exchanges of information. In that context, though, it deserves to be mentioned that restorative justice approaches function generally on a much more informal scale than traditional litigation. Based upon trust and dialogue, restorative justice arrangements require to a lesser extent the proof of an infringement prior to take restorative action. In the same way, the outcome of restorative processes is not necessarily and immediately the payment of compensatory damages. As a result, even in the absence of infringement decisions or of proof to a requisite legal standard of competition law violations, restorative justice initiatives could be initiated if both offender and (a group of) victims agree to it.

Inversely, however, questions may arise as to the extent to which confessions or acknowledgements of wrongdoing made in a private enforcement restorative justice procedure impact on public enforcement. In criminal justice scholarship, restorative justice is presented as an alternative to classical crime and punishment approaches..$^{99}$ In competition law, however, private enforcement is seen as a complement to public enforcement. The major issue to be addressed in this context would therefore be whether restorative justice-based dialogues could entirely replace public enforcement, or should be seen as a complement to it. If they are a complement, measures should be in place not to discourage the use of such procedures, by allowing public authorities to short-cut their own procedures and imposing a fine at the outcome of the process. Given the importance that public enforcement plays in EU competition law, it is likely that such rules may be necessary should one decide to proceed along this way. It can be expected that this is the most important practical limit to setting up a

\footnotetext{
${ }^{99}$ See Howard Zehr, Changing Lenses.
} 
full-fledged restorative justice-oriented framework. Absent rules governing the co-existence of both sets of enforcement structures, it will be difficult to guarantee an effectively functioning antitrust trust fund as proposed here.

It follows from the foregoing that as long as public enforcement remains the key focus of EU competition law enforcement, restorative justice processes are likely to play only subsidiary and subordinate roles compared to public enforcement. That does not mean, however, that the proposals made here may have no chance of being implemented. It is submitted indeed that paying closer attention to restorative justice-oriented processes and implementing them in a more streamlined way may be a first step towards a reframed public-private enforcement balance in the EU. Article 18 of the 2014 Directive has made a modest step in that direction. It would therefore not be completely unexpected if the legislator decides to continue the effort and move forward with restorative justice-oriented processes. Doing so would nevertheless require making policy choices. For that, a more democratic debate on how to proceed in this field would be most welcome. In addition, more comparative research on the usefulness of private trust funds, settlement bodies in U.S. collective action law and restorative justice in competition law would be necessary as well. It can only be hoped that the new European Parliament, in dialogue with the newly composed European Commission, would take steps going in this direction.

\section{Conclusion}

This article addressed the 2014 Private Damages' Directive limited attention for restorative justice processes. It revisited the scope and focus of that Directive prior to concluding that a limited understanding of corrective justice underlies this legal instrument. Aiming to look beyond that narrow understanding, the article subsequently proposed an alternative way forward, consisting in the setup of publicly funded, yet privately managed antitrust trust funds. Discussing the different formats and open questions and choices having to be made when considering such setup, the article at the very least called for a widening of the debate on the desirability and effectiveness of restorative justice-oriented processes and features within EU competition law enforcement. Opening that debate, it was submitted, could lead to a fresh look upon the relationship between public and private enforcement in this field and upon ways to rebalance both types of enforcement. 


\section{Bibliography:}

American Bar Association. Antitrust Class Actions Handbook, Second Edition. Washington: ABA Publishing, 2018.

Androff, David K. "Reconciliation in a community-based restorative justice intervention”. Journal of Sociology and Social Welfare 39, no. 4 (2012): 73-96.

Aristotle. Nicomachean Ethics, Book IV. Available in English at http://classics.mit.edu/ Aristotle/nicomachaen.4.iv.html.

Ashton, David and David Henry. Competition Damages Actions in the EU. Cheltenham: Edward Elgar, 2013.

Bernitz, Ulf. "Introduction to the Directive on Competition Damages Actions". In Harmonising EU Competition Litigation: The New Directive and Beyond, edited by Maria Bergström, Magnus Strand and Marios Iacovides, 3-15. Oxford: Hart, 2016.

Biff, Emmanuela and Tim Chapman. Restorative Justice Responses to Conflicts in Intercultural Settings: Practice Guidelines. Leuven: European Forum for Restorative Justice, 2015. http://alternativefilms.euforumrj.org/e-books/.

Borger, Vestert. The Transformation of the Euro: Law, Contract, Solidarity. Leiden University, PhD thesis, 2018.

Braithwaite, John. "The fundamentals of restorative justice". In A Kind of Mending: Restorative Justice in the Pacific Islands, edited by Sinclair Dinnen, Anita Jowitt and Tess Newton, 35-43. Canberra: ANU Press, 2003.

Braithwaite, John. Restorative Justice and Responsive Regulation. Oxford: Oxford University Press, 2002.

Braithwaite, John. "Restorative justice for banks through negative licensing". British Journal of Criminology 49, no. 4 (2009): 439-450.

Braithwaite, John and Heather Strang. "Restorative justice and family violence". In Restorative Justice and Family Violence, edited by John Braithwaite and Heather Strang, 1-22. Cambridge: Cambridge University Press, 2002.

Brickhouse, Thomas C. "Aristotle on corrective justice”. The Journal of Ethics 18, no. 3 (2014): 187-205.

Cauffman, Caroline. "Access to leniency-related documents after Pfleiderer". World Competition 34, no. 4 (2011): 597-615.

Cauffman, Caroline. "The impact of voidness for infringement of Article 101 TFEU on related contracts”. European Competition Journal 8, no. 1 (2012): 95-122.

Chamon, Merijn. EU Agencies. Legal and Political Limits to the Transformation of the EU Administration. Oxford: Oxford University Press, 2016.

Chroust, Anton-Hermann and David L. Osborn. "Aristotle's conception of justice". Notre Dame Law Review 17, no. 2 (1942): 129-143. 
De Witte, Bruno. "Responses and the EU legal order: Increased institutional variation or constitutional mutation?". European Constitutional Law Review 11, no. 3 (2015): 434-457.

Dunne, Niamh. “Courage and compromise: The directive on antitrust damages". European Law Review 40, no. 4 (2015): 581-587.

Fabbrini, Federico. Economic Governance in Europe. Comparative Paradoxes and Constitutional Challenges. Oxford: Oxford University Press, 2016.

Frese, Michael. Sanctions in EU Competition Law: Principles and Practice. Oxford: Hart, 2016.

García Valdecasas, Rafael and Aitor Montesa Lloreda. "A new life for commitment decisions under Article 9 of Regulation 1/2003? The aftermath of the ECJ Judgment of 29 June 2010 in Case C-441/07P, Commission v. Alrosa". In Today's Multi-Layered Legal Order: Current Issues and Perspectives, edited by Tristan Baumé, Edmon Oude Elferink, Pauline Phoa and Dominique Thiaville, 97-114. Paris: Zutphen, 2011.

Gautier, Axel and Nicolas Petit. "Optimal enforcement of competition policy: The commitments procedure under uncertainty”. https://ssrn.com/abstract=2509729.

Geradin, Damien and David Henry. "The EC fining policy for violations of competition law: An empirical review of the Commission Decisional Practice and the Community Courts' judgments". European Competition Journal 1, no. 2 (2005): 401-473.

Havu, Katri. "Fault in EU competition law damages claims". Global Competition Litigation Review 8, no. 1 (2015): 1-13.

Havu, Katri. "Full, adequate and commensurate compensation for damages under EU law: A challenge for national courts?”. European Law Review 43, no. 1 (2018): 24-46.

Hjärtstrom, Max and Julian Nowag. "EU competences and the Damages Directive: The continuum between minimum and full harmonisation". In EU Competition Litigation: Transposition and First Experiences of the New Regime, edited by Magnus Strand, Vladimir Bastidas and Marios Iacovides, 3-18. Oxford: Hart, 2019.

Henriksson, Lars. "Private enforcement of public law - an inconsistent approach to remedies?". In EU Competition Litigation: Transposition and First Experiences of the New Regime, edited by Magnus Strand, Vladimir Bastidas and Marios Iacovides, 79-95. Oxford: Hart, 2019.

Hensler, Deborah. "Can private class actions enforce marketplace regulations? Do they? Should they?". In Comparative Law and Regulation - Understanding the Global Regulatory Process, edited by Francesca Bignami and David Zaring, 238-272. Cheltenham: Edward Elgar, 2016.

Hodges, Christopher. The Reform of Class and Representative Actions in European Legal Systems. A New Framework for Collective Redress in Europe. Oxford: Hart, 2008. 
Johnston, Jennifer. "Cy pres comme possible to anything is possible: How cy pres creates improper incentives in class action settlements". Journal of Law, Economics \& Policy 9 (2013): 277-304.

Juska, Zygimantas. “Obstacles in European competition law enforcement: A potential solution from collective redress". European Journal of Legal Studies 7, no. 1 (2014): 125-153.

Juska, Zygimantas. The Role of Collective Redress Actions to Achieve Full Compensation for Violations of European Union Competition Law. Leiden University PhD thesis, 2019.

Kloub, Jindrich, "White Paper on damage actions for breach of the EC antitrust rules: Plea for a more holistic approach to antitrust enforcement". European Competition Journal 5, no. 2 (2009): 515-547.

Komninos, Assimakos. EC Private Antitrust Enforcement: Decentralised Application of EC Competition Law by National Courts. Oxford: Hart, 2008.

Landini, Sara. "Private enforcement and market regulation". Market and Competition Law Review 2, no. 2 (2018): 47-71.

Lauwaert, Katrien. "Restorative justice in the 2012 EU Victims Directive: A right to quality service, but no right to equal access for victims of crime". Restorative Justice 1 , no. 3 (2013): 414-425.

Leskinen, Charlotte. "Collective actions: Rethinking funding and national cost rules". Competition Law Review 8, no. 1 (2011): 87-121.

Lianos, Ioanos, Peter Davis and Paolisa Nebbia. Damages Claims for the Infringement of EU Competition Law. Oxford: Oxford University Press, 2015.

Lo Schiavo, Gianni. The Role of Financial Stability in EU Law and Policy. The Hague: Kluwer, 2017.

Maglione, Giuseppe. "Discursive fields and subject positions: Becoming 'victim', 'offender' and 'community' in restorative justice”. Restorative Justice 2, no. 3 (2014): 327-348.

Menkel-Meadow, Carrie. “Restorative justice: What is it and how does it work?". Annual Review of Law and Social Science no. 3 (2007): 10.1-10.27.

Motta, Marco. "On cartel deterrence and fines in the European Union". European Competition Law Review 29, no. 4 (2008): 209-220.

Oliveira Pais, Sofia. "A first look at the Portuguese Act 23/2018 transposing the Private Enforcement Directive". In EU Competition Litigation: Transposition and First Experiences of the New Regime, edited by Magnus Strand, Vladimir Bastidas and Marios Iacovides, 63-75. Oxford: Hart, 2019. 
Oliveira Pais, Sofia and Anna Piszcz. "Package on Actions for damages based on breaches of EU competition rules: Can one size fit all?". Yearbook of Antitrust and Regulatory Studies 7, no. 10 (2014): 209-234.

Parker, Christine. "Restorative justice in business regulation? The Australian Competition and Consumer Commission's use of enforceable undertakings". Modern Law Review 67, no. 2 (2004): 204-246.

Penner, James E. The Law of Trusts. Oxford: Oxford University Press, 2019.

Piszcz, Anna. "Room for manoeuvre for Member States: Issues for decision on the occasion of the transposition of the Damages Directive". Market and Competition Law Review 1, no. 1 (2017): 81-109.

Spalding, Andrew Brady. "Restorative justice for multinational corporations". Ohio State Law Journal 76, no. 2 (2015): 357-408.

Strang, Heather. "Justice for victims of young offenders: The centrality of emotional harm and restoration". In Restorative Justice for Juveniles. Conferencing, Mediation and Circles, edited by Allison Morris and Gabrielle Maxwell, 183-193. Oxford: Hart, 2001.

Tyler, Tom. "Restorative justice and procedural justice: Dealing with rule breaking". Journal of Social Issues 62 (2006): 307-326.

Van Cleynenbreugel, Pieter. "Embedding procedural autonomy: The Directive and national procedural rules". In Harmonising EU Competition Litigation: The New Directive and Beyond, edited by Maria Bergström, Magnus Strand and Marios Iacovides, 99-119. Oxford: Hart, 2016.

Van Cleynenbreugel, Pieter. "Sharing powers within exclusive competences: Rethinking EU antitrust law enforcement". Croatian Yearbook of European Law and Policy 12 (2016): 49-79.

Van Cleynenbreugel, Pieter. "The presumption of harm and its implementation in the Member States' legal orders". In EU Competition Litigation: Transposition and First Experiences of the New Regime, edited by Magnus Strand, Vladimir Bastidas and Marios Iacovides, 201-214. Oxford: Hart, 2019.

Völcker, Sven. "Case C-360/09, Pfleiderer AG v. Bundeskartellamt, Judgment of the Court of Justice (Grand Chamber) of 14 June 2011, nyr". Common Market Law Review 49 (2012): 695-720.

Weinrib, Ernest J. "Corrective justice in a nutshell". The University of Toronto Law Journal 52, no. 2 (2002): 349-356.

Wemmers, Jo-Anne. "Restorative justice for victims of crime: A victim-oriented approach to restorative justice". International Review of Victimology 9 (2002): 43-59. 
Wilman, F. "The end of the absence? The growing body of EU legislation on private enforcement and the main remedies it provides for". Common Market Law Review 53, no. 4 (2016): 887-935.

Wils, Wouter PJ. "Private enforcement of EU antitrust law and its relationship with public enforcement: Past, present and future”. World Competition 40, no. 1 (2017): 3-45. Yeung, Karen. Securing Compliance: A Principled Approach. Oxford: Hart, 2004.

Zehr, Howard. Changing Lenses: Restorative Justice for Our Times, Second Edition. Harrisonsburg: Herald Press, 2015. 